\title{
Effects of low-level laser therapy on the progress of wound healing in humans: the contribution of in vitro and in vivo experimental studies
}

\author{
Efeitos da terapia a laser de baixa intensidade na evolução da \\ cicatrização de lesões em humanos: a contribuição dos estudos \\ experimentais in vitro $e$ in vivo
}

\author{
Adeir Moreira Rocha Júnior ${ }^{1}$, Beatriz Julião Vieira ${ }^{2}$, Luís Carlos Ferreira de Andrade ${ }^{3}$, \\ Fernando Monteiro Aarestrup ${ }^{4}$
}

\begin{abstract}
Low-level laser therapy is an important method for the treatment of healing processes, and several experimental studies have been carried out in search of a greater understanding of its therapeutic possibilities. The objective of this study was to review pathogenetic aspects of soft tissue repair to better understand skin lesion healing and the role of low-intensity laser in the progression of tissue healing. This study consists of a concise review of scientific literature data on the use of low-level laser and its influence on wound healing. Many studies have extensively covered the effects of using laser radiation in tissues, describing its beneficial aspects in tissue healing. However, many unanswered questions demand research on the mechanism of action and on parameters of low-level laser use in different stages of wound repair to clarify how this method acts at a cell level in healing processes.
\end{abstract}

Keywords: LLLT, wound healing.

\section{Introduction}

At present, cutaneous lesions represent a dilemma of global proportions and instigate great clinical interest because of the high morbidity associated with changes in the normal healing process. ${ }^{1}$ Among the clinical aspects involving this issue, we emphasize tissue repair time in an effort to make the process quicker and more harmonious, reduce possible complications in lesion resolution, and allow an adequate choice of therapy. To do this, familiarity with the pathogenesis of

\section{Resumo}

A terapia a laser de baixa intensidade é um importante método de tratamento nos processos cicatriciais, sendo que diversos estudos foram realizados na busca de um maior entendimento das possibilidades deste recurso terapêutico. O objetivo deste estudo foi rever aspectos da patogênese tecidual a fim de compreender melhor a cicatrização de lesões cutâneas e o papel do laser de baixa intensidade na cicatrização tecidual. Este estudo foi conduzido por uma revisão concisa de dados científicos da literatura sobre o uso do laser de baixa intensidade e sua influência na cicatrização de feridas. Diversos estudos relataram os efeitos da radiação a laser nos tecidos, descrevendo seus benefícios na cicatrização tecidual. Entretanto, ainda existem várias dúvidas a serem respondidas, o que exige pesquisas mais detalhadas sobre o mecanismo de ação e os parâmetros utilizados do laser de baixa intensidade nas diferentes fases do reparo das lesões, a fim de esclarecer como este método atua em nível celular nos processos cicatriciais.

Palavras-chave: LLLT, cicatrização de feridas.

tissue healing is necessary, as well as an understanding of the factors affecting the process and the role each one plays in its progress, always seeking a clinical treatment that optimizes skin lesion care. Among the methods currently available, low-level laser therapy (LLLT) stands out.

Allied health professionals regularly care for a variety of skin wounds, such as abrasions, turf burns, surgical incisions, and ulcerations, which are perhaps the most

1. MSc. Student in Brazilian Health, Universidade Federal de Juiz de Fora (UFJF), Juiz de Fora, MG, Brazil.

2. PhD in Pathology, Universidade Federal Fluminense (UFF), Niterói, RJ, Brazil. Researcher, Laboratory of Immunopathology and Experimental Pathology, Centro de Biologia da Reprodução (CBR), UFJF, Juiz de Fora, MG, Brazil.

3. PhD in Nephrology, Universidade Federal de São Paulo (UNIFESP), São Paulo, SP, Brazil.

Trabalho desenvolvido e realizado no Laboratório de Imunopatologia e Patologia Experimental, Centro de Biologia da Reprodução, Universidade Federal de Juiz de Fora, Juiz de Fora, MG.

Manuscript received Feb 28, 2007, accepted for publication June 20, 2007. 
difficult to treat. From acute wound management to augmentation of scar tissue remodeling, the clinician seeks to optimize wound care to promote healing. Experimental in vitro and in vivo studies have been under development since the 1960s, and in the early 1990s, LLLT was approved by the Food and Drug Administration (FDA) as an important method for treating healing processes. ${ }^{2-4}$ Recent results of a study demonstrated that LLLT is an effective method to modulate tissue repair, thus significantly contributing to a faster and more organized healing process. $^{5}$

Nevertheless, in spite of the large number of studies involving this technique and its wide use in clinical practice, the principles of its action in cells and tissues are still not well understood. The objective of this study is to review pathogenetic aspects of soft tissue repair to understand the major complications in skin lesion healing. In addition, it aims at forming a concise compilation of published data from scientific literature to date to verify whether the use of low-level laser influences wound healing, since its mechanisms of action are not fully clear yet.

\section{Skin lesions and the importance of healing process in treatment success}

Some of the most common cutaneous wounds include excoriations, burns, surgical incisions, and acute or chronic ulcerations. ${ }^{2,3}$ Diabetes mellitus is one of the primary predisposing factors for skin lesion development and one of the most common reasons for patients to seek health care, as it represents an important cause of disability and premature death. ${ }^{6}$ According to Pedrosa, ${ }^{7}$ serious cutaneous foot lesions in diabetic patients are the cause for hospital admission in $51 \%$ of patients in endocrinology wards of Brazilian university hospitals. When not properly healed, these lesions represent the main cause of morbidity, immobility and limb amputation, according to data from the American Diabetes Association. ${ }^{6}$

Burn injuries, a clinical condition resulting from direct or indirect action of heat on the human body that causes different degrees of skin lesions, are a significant cause of mortality, primarily due to the infections that can evolve to septicemia. According to the Brazilian
Society of Burn Injuries (Sociedade Brasileira de Queimaduras), there are 1 million cases each year in Brazil. $^{8,9}$ Skin lesions have a great morbidity potential primarily because of complications in the normal healing process. To prevent these complications and promote cure, one needs to understand the normal process of soft tissue repair, as well as the factors that determine its normal healing.

The normal process of soft tissue repair involves the following steps: hemostasis, inflammation ("cleaning"), demolition, proliferation, and maturing. ${ }^{10}$ The homeostatic phase occurs immediately after the appearance of the lesion and depends on platelet activity and on blood coagulation process, which includes a complex release of vasoactive substances, adhesive proteins, and growth factors for the development of other stages. ${ }^{10,11}$ Later on, the inflammatory process sets in with the presence of numerous chemical mediators and inflammatory cells (polymorphonuclear leukocytes, macrophages, and lymphocytes). This phase is responsible for removing necrosed tissue and combating aggressive agents installed in the wound. Next, tissue proliferation, which is responsible for "closing" the wound, sets in, with reepithelization, fibroplasia (matrix formation), and angiogenesis, essential for the supply of oxygen and nutrients needed for healing. Finally, there is wound contraction followed by remodeling, which takes place in the collagen of the region and has the objective of increasing tensile force and diminishing the scar size. ${ }^{11,12}$

Therefore, tissue healing, highlighted as one of the main effects of LLLT, ${ }^{13,14}$ is characterized by three main factors. First, there is an increment of ATP production, as laser is considered to raise the production of ATP, ${ }^{15}$ leading to a boost in mitotic activity and to an increase in protein synthesis by mitochondria, resulting in greater tissue regeneration in the repair process. ${ }^{13,16}$ Second, there is a stimulus to microcirculation, which increases the delivery of nutritional elements associated with increased speed of mitosis, facilitating cell multiplication. ${ }^{13,14}$ Finally, new vessels are formed from preexisting vessels. ${ }^{13,14,17}$

Several factors have a direct influence on tissue healing, altering this process, making it slower, thus allowing complications associated with wound exposure to 
Table 1 - Local and systemic factors that affect the healing process

\begin{tabular}{lc}
\hline \multicolumn{2}{c}{ Factors that influence healing } \\
\hline Local & Systemic \\
\hline Type, size and location & Circulatory conditions \\
Vascular supply & Systemic infections \\
Infection & Metabolic changes \\
Movement & Malnutrition \\
Ionizing radiation - & Hormones \\
X-rays, radiotherapy & \\
Ultraviolet light & Immunosuppression \\
\hline
\end{tabular}

the external environment. The table below displays the key local and systemic factors that affect tissue wound healing (Table 1).

We see, then, that tissue lesions become a route for the installation of problems resulting from exposure to external agents, and therefore there is a need to accelerate the healing process by methods that shorten its duration. Laser therapy has become an important treatment for patients with cutaneous lesions, and there are ongoing studies aimed at understanding and confirming the known effects of laser application in tissue repair.

\section{Low-level laser and its therapeutic use}

The origin of low-intensity laser is attributed to Albert Einstein, who in his article entitled "Zur Quantum Theories der Strahlung" (1917) exposed the main physical principles of stimulated emission (laser phenomenon). This emission was later classified as "highpotency" (with destructive potential) and "low-potency" (without destructive potential). ${ }^{18,19}$

In order to be produced, laser light needs atoms, constituted by a central nucleus, that are positively charged balanced by negatively charged electrons that move around the nucleus in well-defined circular trajectories; in this rotational movement, there is no emission of energy. When the electron passes from one orbit to another, there is a release or absorption of energy called a photon (Figure 1). ${ }^{20}$

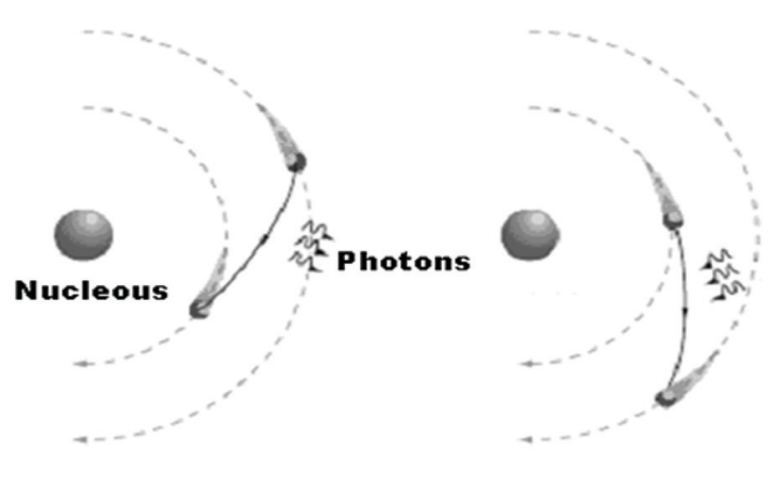

Figure 1 - Rutherford model of atoms, showing electron activity that leads to the process of absorption and emission of photons in orbital transitions

The devices that produce this beam of light are comprised of three parts: a) an active laser medium (gain medium), b) an external energy source, and c) a resonant optical cavity. The gain medium is a gas, solid or liquid containing the atoms that enable photons to leap electron levels emitting photons and constituting a laser light beam. The external energy source furnishes the necessary energy to the system, so that electrons leap levels releasing, and not absorbing energy. This energy source should be able to produce high-energy or excited states. The optical or resonator cavity makes the emerging photons return to the system, producing additional stimulated emissions; this phenomenon occurs by mirrors positioned at the cavity extremities, provoking a reflection of photons back to the sample (Figure 2). ${ }^{14,20,21}$

The differences between the various types of laser beams produced are determined by wavelengths: the shorter the wavelength, the greater its action and power of penetration. Additionally, lasers may be continuous or pulsed, and their potency is expressed in Watts (W), varying from deciwatts to megawatts. Energy is expressed in Joules per square centimeter $\left(\mathrm{J} / \mathrm{cm}^{2}\right)$, and therefore is equal to the potency multiplied by the duration of application. ${ }^{22}$ Knowledge of these parameters is vital for appropriate indication and therapeutic utilization of this method. ${ }^{4}$ 


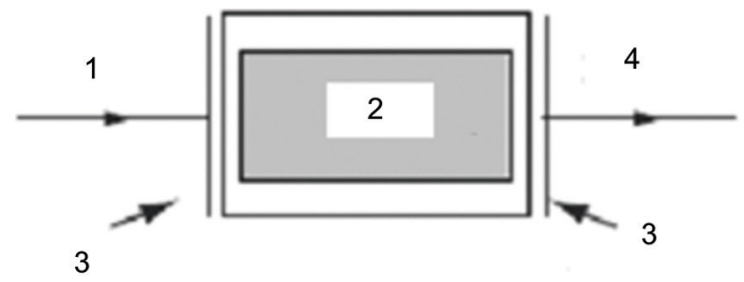

1 - an external energy source

2 - active laser medium

3 - a resonant optical cavity

4 - LLLT

Figure 2 - Simplified scheme of parts that comprise a laser device

\section{Action of laser on tissues and its role in the healing process}

Based on the understanding of the mechanism of laser light origin, we observe that when low-intensity light is used, there is no thermal effect, i.e., the energy from the photons absorbed is not transformed into heat, but into photochemical, photophysical, and photobiological effects. According to Catão, ${ }^{21}$ this is an important principle of the interaction between laser light and cell or tissue specimens. When it is applied at an appropriate dose, laser can stimulate cell functions that are vital for the progress and resolution of the healing process via tissue biostimulation, such as increased mitochondrial ATP production, lymphocyte and mast cell activation, and proliferation of fibroblasts and other cells, besides promoting analgesia and anti-inflammatory effects. $^{21,23}$

As previously stated, the action of laser on tissues depends on the duration of emission of the different energy densities, and on the application area. Therefore, if these parameters are not duly verified and/or calibrated, treatment may be ineffective, compromising therapeutic success. ${ }^{24}$

According to previously established parameters, in cutaneous lesions the tissue layer to be targeted depends on type of laser, potency used and duration of application. Kolárová et al. ${ }^{25}$ observed that, using high potencies or application of light for fractions of a second, the power of penetration of $\mathrm{HeNe}$ radiation with a wavelength of $632 \mathrm{~nm}$ could reach up to $19 \mathrm{~mm}$ of depth in the dermis. ${ }^{25}$ Since the energy produced by the laser is only absorbed by a thin layer of adjacent tissue in addition to the spot targeted by the radiation, current recommendation is to use low-intensity laser that has a low power of penetration, with wavelengths between 640 and $940 \mathrm{~nm}$ in a punctiform application to the lesion. ${ }^{26}$

Several research studies have used superficial wounds to assess the effects of low-intensity laser on healing. Some have used clinical wounds such as ulcers of different sizes and depths ${ }^{3,27,28}$ and others have developed models of superficial wounds in animals. ${ }^{19,29,30}$ These diverse methods have produced a variety of results and conclusions on the effects of LLLT.

\section{Experimental in vitro and in vivo studies (animals and humans)}

Vinck et $a .^{31}$ carried out a cell culture study to observe the influence of diode light emission (LED) and LLLT in the process of wound healing, in which cultures of fibroblasts obtained from 8-day-old chicken embryos were treated for three consecutive days. Infrared laser gallium-aluminum arsenate (GaAlAs - Unilaser 301P, MDB-laser, Belgium) was applied to an area of $0.196 \mathrm{~cm}^{2}$, with an $830 \mathrm{~nm}$ wavelength, peak potency of 1-400 $\mathrm{mW}$, and a frequency of $0-1,500 \mathrm{~Hz}$ LED (BIO - DIO, MDB - laser, Belgium), with three wavelengths emitted separately. All three applications covered an area of $18 \mathrm{~cm}^{2}$ and used a frequency of $0-1,500 \mathrm{~Hz}$, at an application distance of $0.6 \mathrm{~cm}$. LLLT was used with the following parameters: one 5-second emission with a peak potency of $40 \mathrm{~mW}$ resulting in an exposure of $1 \mathrm{~J} / \mathrm{cm}^{2}$. Infrared, the light spectrum with red light, has a radiation exposure of $0.53 \mathrm{~J} / \mathrm{cm}^{2}$. Green light emits $0.1 \mathrm{Jcm}^{2}$, corresponding to an exposure time of 1,2 , and $3 \mathrm{~min}$ utes, respectively, with peak potencies equivalent to 160 , 80 and $10 \mathrm{~mW}$, respectively. Statistical analysis showed a high proliferation of fibroblasts in vitro. Therefore, this study presupposed the possibility of stimulatory effects on in vivo wound healing when treated with LLLT. 
Demir et al. ${ }^{32}$ investigated the effects of electrical stimulation (ES) and LLLT in wound healing in an experimental study using 124 Swiss-albino female rats, with weights between 200 and $240 \mathrm{~g}$, aged 8 to 10 months, which were divided into four groups of 30 animals each. A 6-cm linear incision was made in the dorsal region of each rat. According to the protocol used, group I was treated with ES (Endomed 582 model, Enraf-Nonius Co., Holland). For group II, a similar procedure was stipulated, including a saline solution for application, but without using current. In group III, gallium arsenate laser (Laserpet 100 model, Petas Co., Turkey) was used, with a $904 \mathrm{~nm}$ wavelength, average potency of 6 $\mathrm{mW}$, and a $1 \mathrm{~J} / \mathrm{cm}^{2}$ dose with the maximum frequency of $128 \mathrm{~Hz}$. This dose was applied in a continuous form for 10 minutes a day, over a 10-day period. They concluded that ES and laser treatments have positive effects on inflammation, proliferation, and maturation of wounds, and can be successfully used for decubitus ulcers and chronic wounds.

An experimental study conducted by Khadra ${ }^{33}$ observed the effects of gallium-aluminum arsenate laser (GaAlAs), a diode laser, on bone healing process in 20 rats with $2.7 \mathrm{~mm}$ diameter bone defects in the parietal region treated for 4 weeks. On the 28th day, the animals were euthanized for histological assessment of bone defects. In experimental animal tissues, there was a significant increase in calcium, phosphorus and protein. Similarly, histological analyses showed a marked growth of angiogenesis and connective tissue. They concluded, therefore, that LLLT can favor bone formation in rats with bone defects.

Study of LLLT on the diverse constituents of the extracellular matrix is crucial for an understanding of the healing process using that agent. However, little is known about the influence of laser therapy regarding collagen and elastic fibers. Pugliese et al. ${ }^{34}$ conducted an experimental study in 72 male and female Wistar rats weighing around 150-250 g each, which were divided into three groups. Standard cutaneous wounds were created on the back of the rats, followed by a punctiform application of low-potency gallium-aluminum arsenate - type laser (VR-KC-610, Dentoflex, SP, Brazil) with an emission of $670 \mathrm{~nm}$ diode light and a potency of $9 \mathrm{~mW}$ of different energy densities $-4 \mathrm{~J} / \mathrm{cm}^{2}$ for group II and 8 $\mathrm{J} / \mathrm{cm}^{2}$ for group III. The animals were euthanized at 24 , 48 and 72 hours, and 5, 7 and 14 days. The animals that underwent treatment showed a greater expression of collagen and elastic fibers. In those treated with a $4 \mathrm{~J} / \mathrm{cm}^{2}$ flow, better results were noted than in those treated with an $8 \mathrm{~J} / \mathrm{cm}^{2}$ flow. This study led to the conclusion that laser treatment contributes to a greater expression of collagen and elastic fibers during the healing process.

Over the years, different studies have been performed to understand the tissue repair process, as well as the possible effects of laser therapy on the process of wound healing. Rocha Jr. et al. ${ }^{5}$ carried out a study to investigate the behavior of cutaneous wounds provoked on the dorsal region of Wistar rats (Rattus norvegicus) submitted to low-intensity treatment with a $3.8 \mathrm{~J} / \mathrm{cm}^{2}$ dose, $15 \mathrm{~mW}$ of potency, and $15 \mathrm{~s}$ of application time. The animals $(\mathrm{n}=12)$ were divided into two groups, one control and the other treated with laser. In the treated group, three applications were given (immediately following the surgical act, 48 hours, and 7 days after surgical wounds were created). Ten days after the operation, lesion samples were collected from both groups for histopathologic and histomorphologic studies. Results showed increased neovascularization and fibroblast proliferation, as well as decreased quantity of inflammatory infiltrate in the surgical lesions submitted to laser treatment. In the control group, abutting the margin of the surgical wound, a discrete epithelial proliferation was noted, and along practically the whole extension there was presence of a tissue with a wide area of ulceration and fibrinonecrotic tissue over the granulation tissue (Figure 3). Conversely, in laser-treated group II, histopathologic study showed material with an intact epidermis lining well-developed granulation tissue with a connective tissue rich in collagen fibers parallel to the surface of the wound, characterizing a better-organized tissue repair process (Figure 4). Clinical observation of skin lesion samples of the animals showed that skin lesions of group I (control) exhibited an early-phase tissue repair pattern, with formation of a whitish crust, with slightly elevated rims and a reddish core due to accentuated presence of blood irrigation in that area, indicating presence of granulation tissue. On the other hand, group II wounds, which were submitted to LLLT, 
showed complete tissue repair, showing scars with evident rims and a central portion slightly unleveled, but presenting advanced morphological and functional recovery of involved tissues (Figure 5). These combined results suggest that LLLT is an efficacious method of tissue repair modulation, significantly contributing to a more rapid and organized healing of tissues.

Experimental treatment in patients began in the 1970s after reports of positive results of radiation with LLLT of cell cultures and animal experiments. ${ }^{4}$ Nevertheless, this initial success in cell cultures and animal studies is controversial, and further studies need to be conducted to analyze its usefulness in treating skin lesions in humans. ${ }^{35}$

Gaida et al. ${ }^{36}$ conducted a study in humans with the objective of confirming the effects of LLLT and its prophylactic use in treating burn healing, since the beneficial effects of LLLT in wound healing are still

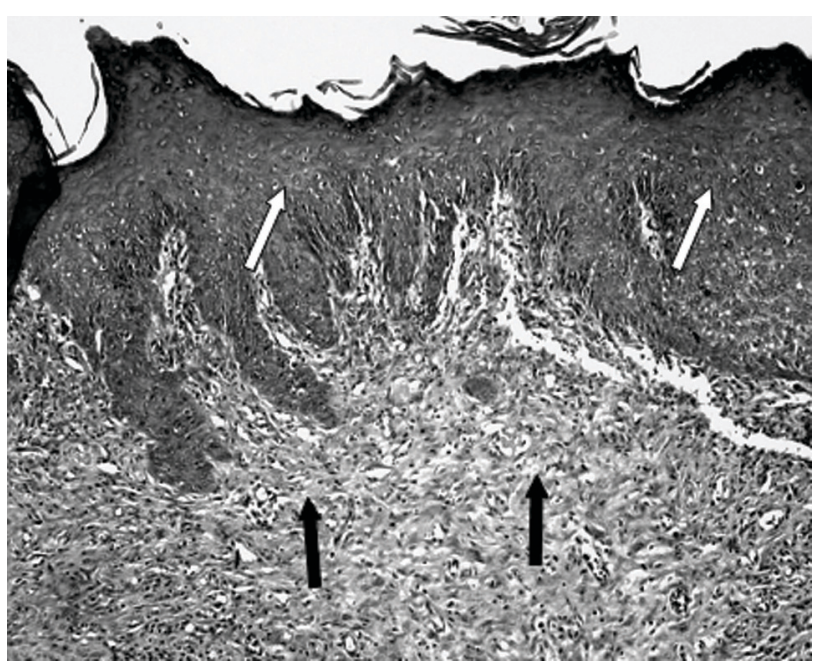

Figure 4 - Cutaneous sample of treated animal showing intact epidermis with presence of hyperplasia (white arrows) covering well-developed granulation tissue (black arrows). Hematoxylin-eosin stain, total magnification $50 \mathrm{x}$

controversial. That study included 19 patients (14 men and five women, aged between 18-77 years), in which one burn from each patient was chosen for radiation,

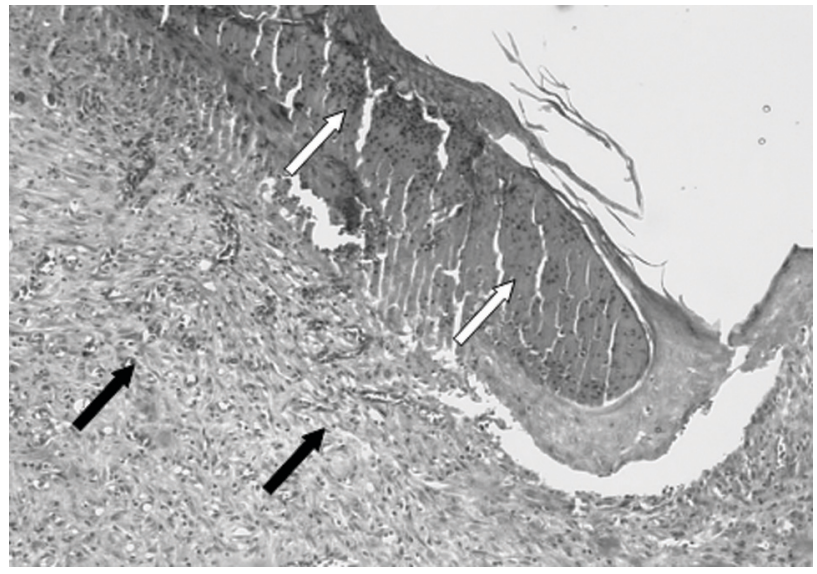

Figure 3 - Cutaneous sample of a control animal exhibiting a wide area of ulceration and fibrinonecrotic material (white arrows) on granulation tissue (black arrows). Hematoxylin-eosin stain, total magnification $50 \mathrm{x}$

and another similar burn was defined as control. Burns were located on the face, trunk and limbs. LLLT was administered with a soft laser device (Helbor, Gallspach, Austria) with a circular application of a continuous diode laser using a $400 \mathrm{mw}$ potency emitting a red laser light with a $670 \mathrm{~nm}$ wavelength. Dose used was 4 $\mathrm{J} / \mathrm{cm}^{2}$. Treatment was given twice a week, with a minimal interval of 3 days for 8 weeks. Seventeen out of 19 lesions attained macroscopic improvement with treatment, and two did not. That study concluded that LLLT could have significant beneficial effects on patients during rehabilitation.

Lucas et al. ${ }^{37}$ developed a study in humans with a wide sample, in which they observed the benefits of LLLT in treating stage III decubitus ulcers. The study was carried out in 86 patients; one group $(n=47)$ was treated with changes in decubitus, and the other $(n=39)$ also received LLLT five times a week for 6 weeks. Early results showed a relative decrease in wound area after 6 weeks compared to initial conditions. LLLT was administered using a $904 \mathrm{~nm}$ infrared gallium arsenate laser (GaAs-diode) radiating an area of $12 \mathrm{~cm}^{2}$, in a 125 -s exposure. Peak potency was 12 x $70 \mathrm{~W}$ with $830 \mathrm{~Hz}$ of frequency and a $150 \mathrm{~ns}$ pulse, with an average potency 


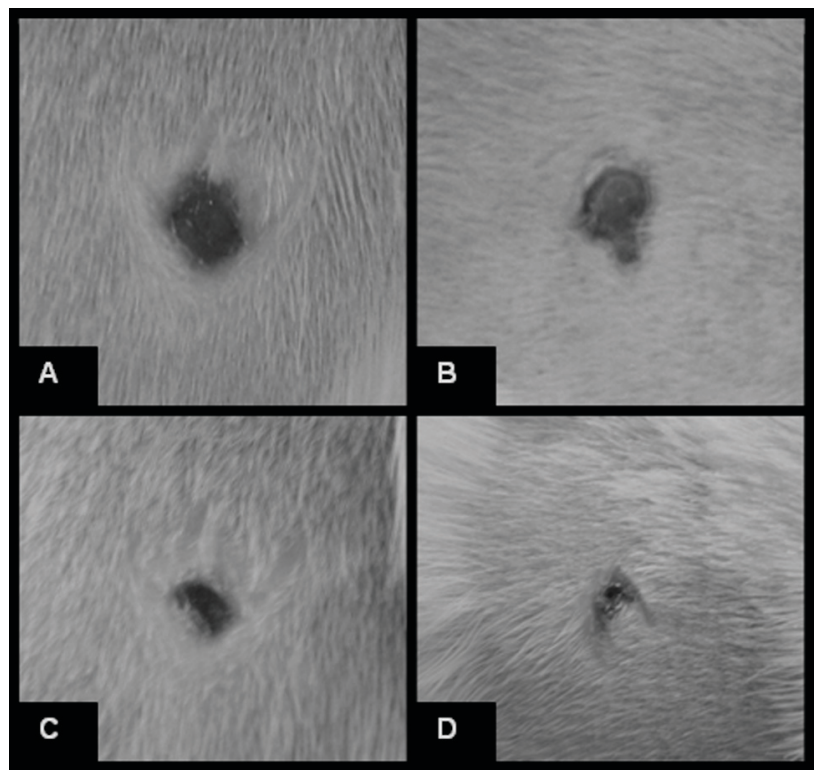

Figure 5 - Macroscopic characteristics of rat skin lesion (control group, A and C; treated group, B and D). A and B) Early-phase tissue repair pattern 7 days after surgical incision. Note a larger lesion diameter observed in the control animal; $\mathrm{C}$ and D) tissue repair pattern 10 days after surgical incision. The rat treated by low-level laser therapy presented a complete tissue repair and showed advanced morphological recovery of involved tissues

of $12 \times 80 \mathrm{~mW}$ and radiation of $1 \mathrm{~J} / \mathrm{cm}^{2}$, in a 125 -s exposure. During treatment period, $11 \%$ of the control patients and $8 \%$ of the patients in the group treated with LLLT developed stage IV decubitus ulcers. Considering both groups in terms of lesion improvement, there were no significant differences between them. Therefore, this study did not confirm findings that support use of LLLT as a supplement to decubitus ulcer treatment.

In a clinical case presentation, Legan et al. ${ }^{38}$ carried out a study in humans to investigate the clinical effects of LLLT in venous ulcerations when used along wound margins, as well as the relevance of this treatment on wound debridement and measurements of affected area. Patients were seen three times a week for 8 weeks using a $830 \mathrm{~nm}$ emission with $9 \mathrm{~J} / \mathrm{cm}^{2}$ in association with a process of wound sterilization at each visit. The lesions and their measurements were analyzed using videos and photos that displayed a $15 \%$ decrease in those areas at the end of the study. It was concluded that LLLT is an effective treatment for patients who suffer from venous ulcers, since LLLT favored stabilization of clinical status and increased the therapeutic effects of these doses in studied groups.

Investigations on the effect of multiple exposures of LLLT on cell responses of wounded skin fibroblasts demonstrate that correct energy density or fluence and number of exposures can stimulate cell responses of wounded fibroblast and promote cell migration and cell proliferation by stimulating mitochondrial activity and maintaining viability without causing additional stress or damage to wounded cells. Results indicate that the cumulative effect of lower doses determines the stimulatory effect, whereas multiple exposure at higher doses result in an inhibitory effect with more damage. ${ }^{39}$

In an experimental study, Byrnes et al. ${ }^{40}$ investigated the effects of photobiomodulation (PBM) on the process of skin wound healing in an animal model (Psammomy obesus rats) with type II diabetes. Results showed histological improvement in wound healing followed by wound closure with the treatment according to the protocol using $4 \mathrm{~J} / \mathrm{cm}^{2}, 16 \mathrm{~mW}$ potency, $250 \mathrm{~s}$ of application for 4 consecutive days. This $4 \mathrm{~J} / \mathrm{cm}^{2}$ dose caused histological improvement in wound closure in diabetic rats compared with non-diabetic rats, with increased expression of fibroblastic growth factor. These findings showed that PBM, with an energy intensity of $4 \mathrm{~J} / \mathrm{cm}^{2}$, is effective in improving lesion healing processes in model animals with type II diabetes, suggesting that PBM (632 $\mathrm{nm}, 4 \mathrm{~J} / \mathrm{cm}^{2}$ ) may be a promising treatment for chronic wounds in diabetic patients.

Houreld et al. ${ }^{41}$ investigated in vitro exposure of wounded diabetic fibroblast cells to a helium-neon laser at 5 and $16 \mathrm{~J} / \mathrm{cm}^{2}$. Cells exposed to $5 \mathrm{~J} / \mathrm{cm}^{2}$ showed a higher rate or migration than cells exposed to $16 \mathrm{~J} / \mathrm{cm}^{2}$, and there was complete wound closure by the fourth day. Exposure of cells to $5 \mathrm{~J} / \mathrm{cm}^{2}$ on two non-consecutive days did not induce additional cytotoxicity or genetic damage, whereas exposure to $16 \mathrm{~J} / \mathrm{cm}^{2}$ did. There was a significant increase in apoptosis in exposed cells compared with unexposed cells. 


\section{Conclusion}

Although various studies have extensively covered the effects of laser radiation on tissue, many unanswered questions remain. The mechanisms effectively responsible for cell mitotic activity have not been clarified yet, and there is no standardized ideal dose for stimulating tissue healing. Therefore, we noted that there is a need for research on the action and parameters of lowintensity laser use in cutaneous lesions during the different stages of repair, as an attempt to elucidate how this method acts at a cell level in healing processes. Elucidation of these issues will enable the establishment of criteria on the true benefits of laser therapy in diseases that need healing stimulation, minimizing healing time and the complications that may occur during the clinical progress of these wounds. In addition, experimental studies indicated that the LLLT may be an important therapeutic tool to stimulate wound healing in diabetic patients.

\section{References}

1. Snyder RJ. Treatment of nonhealing ulcers with allografts. Clin Dermatol. 2005;23:388-95.

2. Sugrue ME, Carolan J, Leen EJ, Feeley TM, Moore DJ, Shanik GD. The use of infrared laser therapy in the treatment of venous ulceration. Ann Vasc Surg. 1990;4:179-81.

3. Chromey PA. The efficacy of carbon dioxide laser surgery for adjunct ulcer therapy. Clin Podiatr Med Surg. 1992;9:709-19.

4. Nussbaum EL, Zuylen JV, Baxter GD. Specification of treatment dosage in laser therapy: unreliable equipment and radiant power determination as confounding factors. Physiother Can. 1999; 157-167.

5. Rocha Jr. AM, de Oliveira RG, Farias RE, de Andrade LCR, Aarestrup FM. Modulation of fibroblast proliferation and inflammatory response by low-intensity laser therapy in tissue repair process. An Bras Dermatol. 2006;81:150-6.

6. Economic consequences of diabetes mellitus in the U.S in 1997. American Diabetes Association. Diabetes Care. 1998;21:296-309.

7. Pedrosa HC. Pé diabético: aspectos histopatológicos, tratamento e prevenção. Rev Bras Neurol Psiquiatr. 1997;1:131-5.

8. Ramos-e-Silva M, Ribeiro de Castro MC. New dressings, including tissue-engineered living skin. Clin Dermatol. 2002;20:715-23.

9. Sheridan RL, Thompkins RG. What's new in burns and metabolism. J Am Coll Surg. 2004;198:243-63.

10. Contran RS, Kumar V, Collins T. Robbins. Patologia estrutural e funcional. Rio de Janeiro: Guanabara Koogan; 2001. p. 44-100.
11. Mandelbaum SH, Di Santis EP, Mandelbaum MHS. Cicatrização: conceitos atuais e recursos auxiliares: parte I. An Bras Dermatol. 2003;78:393-408.

12. Tanaka A, Hatoko M, Tada H, Iioka H, Niitsuma K, Miyagawa S. Expression of p53 family in scars. J Dermatol Sci. 2004;34:17-24.

13. Silva EC, Filho AH, Musskopf DE. Radiação laser. In: Rodrigues EM. Manual de recursos terapêuticos. Rio de Janeiro: Revinter; 1998. p. 17-35.

14. Tavares MR, Mazzer N, Patorello M. Efeito do laser terapêutico na cicatrização tendinosa: estudo experimental em ratos. Fisioter Bras. 2005;6:96-100.

15. Karu T, Pyatibrat L, Kalendo G. Irradiation with He-Ne laser increases ATP level in cells cultivated in vitro. J Photochem Photobiol B. 1995;27:219-23.

16. Herrero C. Los efectos terapeuticos. Bol Sociedad Española Láser Médico Quirúrgico. 1988;15:22-6.

17. Bibikova A, Belkin V, Oron U. Enhancement of angiogenesis in regenerating gastrocnemius muscle of the toad (Bufo viridis) by low-energy laser irradiation. Anat Embryol (Berl). 1994;190:597-602.

18. Mester AF, Mester A. Wound healing. Laser Ther. 1989;1:7-15.

19. Hopkins JT, McLoda TA, Seegmiller JG, Baxter GD. Lowlevel laser therapy facilites superficial wound healing in humans: a triple-blind, sham-controlled study. J Athl Train. 2004;39:223-9.

20. Bagnato VS. Os fundamentos da luz laser. Fís Esc. 2001;2:4-9.

21. Catão MHCV. Os benefícios do laser de baixa intensidade na clínica odontológica na estomatologia. Rev Bras Patol Oral. 2004;3:214-8.

22. Dallan LAO, Oliveira SA. Cirurgia de revascularização transmiocárdica a laser de CO2. Rev Bras Cir Cardiovasc. 2000;15:89-104.

23. Gomez-Villamandos RJ, Santisteban Valenzuela JM, Ruiz Calatrava I, Gomez-Villamandos JC, Avila Jurado I. He-Ne laser therapy by fibroendoscopy in the mucosa of the equine upper airway. Lasers Surg Med. 1995;16:184-8.

24. Weis LC, Arieta A, Souza J, Guirro RRJ. Utilização do laser de baixa potência nas clínicas de fisioterapia de Piracicaba, SP. Fisioter Bras. 2005;6:124-9.

25. Kolárová H, Ditrichová D, Wagner J. Penetration of the laser light into the skin in vitro. Lasers Surg Med. 1999;24:231-5.

26. Parizotto NA, Baranauskas V. Structural analysis of collagen fibrils after $\mathrm{HeNe}$ laser photostimulated regenerating rat tendon. In: 2o Congress World Association for Laser Therapy; Sep 2-5. Kansas City. Proceedings. Kansas City; 1998. p. 66.

27. Gogia PP, Hurt BS, Zirn TT. Wound management with whirlpool and infrared cold laser treatment. A clinical report. Phys Ther. 1988;68:1239-42.

28. Lundeberg T, Malm M. Low-power HeNe laser treatment of venous leg ulcers. Ann Plast Surg. 1991;27:537-9.

29. Allendorf JD, Bessler M, Huang J, et al. Helium-neon laser irradiation at fluences of 1,2 , and $4 \mathrm{~J} / \mathrm{cm} 2$ failed to accelerate wound healing as assessed by wound contracture rate and tensile strength. Lasers Surg Med. 1997;20:340-5. 
30. Lucas C, Criens-Poublon LJ, Cockrell CT, de Haan RJ. Wound healing in cell studies and animal model experiments by Low Level Laser Therapy; were clinical studies justified? a systematic review. Lasers Med Sci. 2002;17:110-34.

31. Vinck EM, Cagnie BJ, Cornelissen MJ, Declercq HA, Cambier DC. Increased fibroblast proliferation induced by light emitting diode and low power laser irradiation. Lasers Med Sci. 2003;18:95-9.

32. Demir H, Balay H, Kirnap M. A comparative study of the effects of electrical stimulation and laser treatment on experimental wound healing in rats. J Rehabil Res Dev. 2004;41:147-54.

33. Khadra M, Kasem N, Haanaes HR, Ellingsen JE, Lyngstadaas SP. Enhancement of bone formation in rat calvarial bone defects using low-level laser therapy. Oral Surg Oral Med Oral Pathol Oral Radiol Endod. 2004;97:693-700.

34. Pugliese LS, Medrado AP, Reis SR, Andrade Z de A. The influence of low-level laser therapy on biomodulation of collagen and elastic fibers. Pesqui Odontol Bras. 2003;17:307-13.

35. Bie RA de, Vet HCW de, Wildenberg FAJM van den, Lenssen TF, Bouter LM, Knipschild PG. Efficacy of laser therapy in ankle sprains: design of a randomised clinical trial. Laser Ther. 1997;9:165-72.

36. Gaida K, Koller R, Isler C, et al. Low Level Laser therapy--a conservative approach to the burn scar? Burns. 2004;30:362-7.

37. Lucas C, van Gemert MJ, de Haan RJ. Efficacy of low-level laser therapy in the management of stage III decubitus ulcers: a prospective, observer-blinded multicentre randomised clinical trial. Lasers Med Sci. 2003;18:72-7.
38. Lagan KM, Mc Donough SM, Clements BA, Baxter GD. A case report of low intensity laser therapy (LILT) in the management of venous ulceration: potential effects of wound debridement upon efficacy. J Clin Laser Med Surg. 2000;18:15-22.

39. Hawkins D, Abrahamse H. Effect of multiple exposure of lowlevel laser therapy on the cellular responses of wounded human skin fibroblasts. Photomed Laser Surg. 2006;24:705-14.

40. Byrnes KR, Barna L, Chenault VM, et al. Photobiomodulation improves cutaneous wound healing in an animal model of type II diabetes. Photomed Laser Surg. 2004;22:281-90.

41. Houreld N, Abrahamse H. In vitro exposure of wounded diabetic fibroblast cells to a helium-neon laser at 5 an $16 \mathrm{~J} / \mathrm{cm} 2$. Photomed Laser Surg. 2007;25:78-84.

Correspondence:

Fernando Monteiro Aarestrup

Centro de Biologia da Reprodução - CBR, Universidade Federal de Juiz de Fora, Campus Universitário, Bairro Martelos

CEP 36036-330 - Juiz de Fora, MG - Brazil

Tel.: +55 (32) 3229.3250

Fax: +55 (32) 3229.3251

E-mail: fmastrup@excite.com 